\title{
Cultivating Rice and Votes: The Institutional Origins of Agricultural Protectionism in Japan
}

\author{
Yusaku Horiuchi and Jun Saito
}

\begin{abstract}
We explore in this article an institutional foundation of agricultural protectionism in Japan, a country long recognized as resisting international pressures to open up its rice market. Using our qualitative analysis of postwar politics of agricultural protectionism and a simple formal model, we argue that farmers in Japan have stronger incentives to mobilize electoral support for the governing party in multimember district systems than in single-member district systems, because the marginal effects of mobilization on policy benefits are different under these electoral systems. Our empirical findings corroborate this claim and provide implications for the gradual changes in Japan's farm policies occurring after the electoral reform in 1994.
\end{abstract}

KEYWORDS: electoral systems, protectionism, agrarian politics, mobilization, natural experiment, SNTV, MMD, Japan

$\mathrm{n}$ this article, we explore an institutional foundation of agricultural protectionism in Japan, a country long recognized as resisting international pressures to open up its rice market. ${ }^{1}$ Despite the fact that the Japanese government still protects rice farmers from international competition by prohibitively high tariff rates and nontariff barriers, ${ }^{2}$ there has been a sequence of gradual changes in Japan's farm policies since the early 1990s (e.g., Davis and Oh 2007; Honma, George-Mulgan, and Godo 2004; Shogenji 2006). Specifically, Japan's farm policy has shifted its target beneficiaries from part-time farmers to full-time counterparts who are willing to increase the efficiency of farm production. In late 1993, the government authorized minimal access to imported rice and later pushed to increase average domestic farm acreages and enhance the productivity of rice faming. The Rice Policy Reform Charter (Kome Seisaku Kaikaku 
Taiko), adopted in late 2002, set an acreage threshold for the provision of subsidies, and small farms were excluded from the protective policy package. Entry barriers into farming were relaxed, and modern managerial entities (e.g., corporate ventures) were allowed to cultivate rice paddies alongside landowning farmers. Furthermore, the producer prices of rice have become increasingly subjected to market forces.

Scholars and the media tend to attribute these changes to changing international environments; specifically, they regard them as consequences of the 1994 adoption of the Uruguay Round Agreement on Agriculture (e.g., Davis and Oh 2007). While we do not necessarily disagree with such a view, we argue that changing domestic incentive mechanisms also matters. Specifically, we point out that these changes took place in the period after the 1994 Lower House electoral reform and argue that this overlap is not a coincidence. When Victorian Britain made a transition from multimember district (MMD) to single-member district (SMD) systems, the Corn Laws were abolished and the trade policy became gradually oriented toward free trade (Cox 1987; Grampp 1987). Our analysis suggests that similar, institutionally rooted changes are taking place in Japan.

We acknowledge that studies of the impact of political institutions on protectionism are not new. Their primary focus, however, has been placed on how much policymakers are susceptible to lobbying pressures under alternative institutional arrangements (e.g., Karol 2007; Milner and Rosendorff 1997; Nielson 2003; Park and Jensen 2007; Rogowski 1987). ${ }^{3}$ The existing explanations about Japan's changing farm policies, which we noted earlier, also focus on how much international pressure has helped policymakers deal with resistance from farmers. These studies have assumed, often implicitly, that farmers' ability to overcome the collective action problems and the intensity of their rent-seeking efforts is determined exogenously and independently of political institutions.

We argue that different electoral institutions provide farmers with varying incentives to mobilize votes for the party that provides them with protective measures. Specifically, we hypothesize that Japanese farmers, who play an important role as active campaigners, have stronger incentives to mobilize electoral support for the governing party in MMDs than in SMDs. In an MMD system, farmers expect that the number of winning candidates the farmers support (and the amount of benefits delivered) is reflective of their mobilization efforts. In contrast, in a SMD system, the expected marginal effects of mobilization on policy benefits are not always large enough for farmers to expend efforts to mobilize nonfarmers to vote for their favored candidate. 
One problem in studying the motivation of farmers to become involved in electoral politics in Japan, however, is the difficulty in obtaining data that directly measure the intensity of demand for protection-for instance, quantitative measures of lobbying efforts by farmers and agricultural organizations. ${ }^{4}$ Thus, we take an indirect approach to draw inference about directly unobservable motivations. First, instead of using variables that measure policy outcomes per se (e.g., tariff rates and nontariff barriers), we use the governing coalition's vote share as our dependent variable and attempt to understand conditions under which profarmer parties receive larger support. Second, we use a new independent variable, which measures the magnitude of crop damage caused by bad weather, blight, and insects, and examine how the damage affects electoral outcomes in MMDs and SMDs. The exogenous variation of crop damage provides a natural experimental setup, because farmers most eagerly seek assistance-if they indeed want and expect it-from the party in power and mobilize votes for the party when their incomes are hit hard by exogenous shocks. In other words, a natural disaster is a "litmus test" for extending inference about farmers' electoral behavior intended to elicit protective measures by the government. The results of our analysis indeed show that the effect of crop damage on the government coalition's vote share in Lower House elections is significantly positive in MMDs but not in SMDs. ${ }^{5}$

To validate our causal interpretation, we also conduct an in-depth qualitative analysis of the postwar politics of agricultural protectionism in Japan. We argue that Japanese farmers were motivated to involve themselves in the active electoral mobilization process when they needed to elicit assistance from the government, particularly when natural disasters whittled down their farm income. ${ }^{6}$ Specifically, parttime rice farmers who cultivate tiny rice paddies pursue politically generated rents and actively mobilize votes as campaigners, especially when natural disasters hit their farm incomes. This substitution between farm and political incomes, however, works more strongly in MMDs than in SMDs.

\section{Postwar Agricultural Politics in Japan}

In this section, we briefly describe important characteristics of Japan's farm sector. We first point out that, throughout the postwar period, the governing party—specifically, the Liberal Democratic Party (LDP)— 
has provided generous support to small-sized, part-time farmers who cultivate tiny rice paddies. We emphasize that these protective measures kept these farmers' incomes extremely susceptible to political discretion. Because of these peculiar features, rice farmers were induced to commit themselves to the LDP's electioneering as active campaigners through their "rice roots" network (Fukui and Fukai 1996; George-Mulgan 2000).

\section{Politics of Protecting Rice Farms}

As in other Asian countries, the traditional farm sector in Japan was characterized by labor-intensive farming in rice paddies of tiny sizes (Hayami 1991). From the early Meiji period until the early 1950s, the average size of a Japanese farm was only 2.4 acres, and the total number of workers in the agricultural sector was about 15 million, roughly 40-50 percent of the working population (Yamada 1991). Although the share of farm employment declined sharply with the rapid growth of the industrial and service sectors during the postwar decades, a nontrivial portion of these farmers could choose to retain their paddies and cultivate them on a part-time basis (McDonald 1996). ${ }^{7}$ This outcome is largely due to the LDP's farm policy, which effectively curbed migration from rural areas to large cities and helped the party sustain their electoral stronghold in rural communities (Watanabe 1998, 245). Given their small sizes, most of these rice farms were barely profitable on their own. If these farmers had not received support from the government or had not diversified the portfolio of their income sources by having politically generated side jobs that paid as well as, or better than, their farm revenues, most of these farmers would have had to sell their properties and migrate to urban areas when exogenous shocks, such as natural disasters and market fluctuations, hit their farms.

It is also worth noting that due to the water-intensive nature of rice farming, villagers somehow needed to coordinate their water usage; this functional demand led to the culture of effective communal monitoring and compliance (Haley 2008). This preexisting village structure accompanied by the low mobility of rice farmers facilitated stable, long-term political transactions within each local community. In addition, as we detail subsequently, these rice farmers became a solid support base for the LDP in exchange for selective benefits provided by the LDP's clientelistic organizations.

In explaining why Japanese farmers became politically dependent, we also need to highlight the fact that the Japanese government has pro- 
tected farmers by means of price-fixing practices-specifically, outright price support and import restriction (at least until the early 1990s). Since producer prices of rice were politically determined and set above market-clearing levels, the government has also assigned strict acreage control measures (gentan) to reduce surplus production of rice.

Although the benefits of price support and import restriction have been pervasive, these price distortionary methods alone do not explain why farmers were dependent on the LDP for protection. In fact, during the period when rice prices were politically determined, the platforms of almost all opposition parties called for higher prices than that of the LDP. Had the electoral competition simply been bidding races for higher producer prices, the opposition party could have successfully stolen the LDP's farm votes. Price support is a nonexclusive method of protection whereby even farmers who do not vote for the LDP can reap the benefit. In this sense, to understand the strong political ties between the LDP and part-time rice farmers, we also need to consider the set of benefits provided selectively within each local farm community.

First, the LDP government has targeted distributive benefits disproportionately in favor of farmers who would cast their ballots for the party and who would also mobilize their family, relatives, friends, and neighbors. When pork barrel projects are provided to their local communities, farmers seek nonfarm employment opportunities while simultaneously cultivating rice. Since farming itself is rarely profitable or sustainable even with artificially inflated producer prices for rice, farmers depend heavily on government-subsidized projects and subsidized loans (particularly for irrigation and machinery investment) intermediated by agricultural cooperatives (Nokyo). Subsidized capital investment also increases the amount of farmers' available time for side jobs because the productivity of their labor input is enhanced by replacing cows and horses with tractors (Hayami and Kawagoe 1991).

Another important selective method of protection has been the government's generation of jobs and incomes for rice farmers through specifically selected actors in rural communities, which include Nokyo, Tochi Kairyo-ku (Land Improvement Districts, LIDs), and construction companies (Hirose 1981). Most rice farmers have sustained their living by combining incomes from politically susceptible agricultural and nonagricultural income sources. The LDP government delivered irrigation projects to get local LIDs to bulldoze and consolidate small segments of rice paddies without affecting per-household farm sizes. Local 
construction companies received the orders and hired farmers. Nokyo lent money to farmers for these subsidized irrigation projects at below market interest rates, and the total project costs were diluted by the government budget. This iron triangle, or "rural-industrial complex," of Nokyo, LIDs, and construction companies became an important cornerstone of the LDP's electoral politics (Fukui and Fukai 1996).

Nokyo has always been the single most important vertex of this triangle, and its national peak organization Zenchu (Central Union of Agricultural Cooperatives) played a pivotal role in collective bargaining between the government and the farmers. Although there is no legal provision requiring that farmers be affiliated with Nokyo, virtually all farmers are members and use services provided by its local branches. ${ }^{8}$ Unlike agricultural cooperatives in other countries of the Organisation for Economic Co-operation and Development (OECD), Nokyo's scope of business is far wider and includes banking, real estate, travel agencies, supermarkets, and even funeral homes. Furthermore, Nokyo is granted an exceptional status in the antitrust law and, as a result, has enjoyed monopolistic control over the factor inputs (e.g., fertilizers, pesticides, and farm machinery), the rural financial market, and the collection of rice harvests. Because most farmers borrow money from Nokyo at below-market interest rates whenever they buy fertilizers and farm machinery, local branch offices of Nokyo effectively control the fate of each farm household. However, most local organizations of Nokyo have been suffering from chronic deficits, becoming dependent on government relief measures. ${ }^{9}$

Construction companies that depend heavily on government-subsidized projects also provided part-time farmers with side jobs. In the 1960s and 1970s, farmers would spend winter months in construction sites in metropolitan areas as seasonal workers (dekasegi). After the mid-1970s, incumbents elected from farm districts tried harder to bring projects to their home districts instead of intermediating seasonal job opportunities in distant cities. Seasonal migration effectively stopped by the 1980 s, but this trend was concomitant with a massive inflow of construction projects to rural areas (Curtis and Ishikawa 1983).

As such, the LDP's local political machines wielded sufficient power to decide the fate of small rice farms, which were barely profitable. Their sustainability was contingent on nonfarm incomes, especially when natural disasters caused severe crop damage. Thus, rice farmers developed dependence on selective policy benefits directly and 
indirectly provided by the LDP's clientelistic organizations, in particular Nokyo and construction companies.

\section{Rice Farmers as Campaigners}

One remaining question is why the party has protected rice farmers despite the fact that the percentage of rice farmers in the total voting-age population in Japan has steadily declined. We show here that it is because rice farmers, who are subject to discretionary policy measures for their own survival, would often play key roles as campaigners for the ruling party, in addition to providing their own bloc votes.

We can identify two contributing factors that explain why rice farmers became excellent campaigners and mobilized votes effectively for the LDP. First, the two notable institutional features we explained earlier-the preexisting structures of village communities, together with the dense network of Nokyo-serve as the hub of get-out-the-vote activities. Contemporary theories of voting behavior emphasize the role mobilization efforts play in generating election results (e.g., Rosenstone and Hansen 1993). In this context, Japanese rice farmers, who are dependent on protection and have dense social networks, have satisfied most of the important qualifications that mobilization theorists would envision. These farmers, whose subsistence has been contingent on political discretion, are the people who pasted LDP candidates' posters on electoral signboards and utilized family and communal ties to mobilize support for the LDP. Even when the number of urban residents was increasing rapidly, these new urban dwellers had their immediate relatives in rural communities. Their parents were the agents who made phone calls to persuade their children to vote for the LDP.

Second, under these institutional settings, the dominant party had the technology to monitor whether villagers indeed supported the party. If provision of subsidies and nonfarm jobs was contingent on villagers' electoral support, the governing party needed to verify their voting behavior and punish those who reneged in the voting booths. Without an effective mechanism of monitoring and punishment, the governing party's vote-buying politics were bound to fail (Stokes 2005). Unlike punch card or check-off paper ballots used by many contemporary democracies, Japanese voters need to write out candidates' names in halfopen voting booths. Senior members of local communal organizations often monitor the polling stations for the sake of fairness in voting conduct. By observing the specific number of strokes used to make Japa- 
nese characters, those who are watching the voters from behind can identify, even imperfectly, the candidate for whom voters cast their ballot (Ishikawa 1999). In typical rural communities in Japan, each voting station covers only a few hundred households, and the process of voting takes place in an environment where candidates can estimate who voted for whom with surprising accuracy (Horiuchi 2005). With these mechanisms of monitoring and enforcement, the governing party has the capacity to reward farmers who campaigned for the party and punish those who defected. The combination of pork barrel projects, subsidized loans, and nonfarm jobs bolsters this process. Farmers, especially those who need access to politically generated income in difficult times, are induced to work hard to mobilize votes for the party.

\section{Electoral Systems and Agricultural Protectionism in Japan}

As we detailed in the preceding section, the provision of politically generated incomes in exchange for votes for the governing party characterizes the pattern of clientelism and agricultural politics in Japanese rural communities. Upon closer examination, however, it appears that this farmer-politician relationship depends on specific electoral institutions. In this section, we point out that Japanese farmers have a stronger incentive to divert their efforts away from farm production into electoral mobilization under a single nontransferable vote (SNTV) system with MMDs. Under an SMD system, this mechanism of substitution does not work well. We provide both contextual descriptions and a formal model that explore this feature of electoral politics.

\section{Farm Policy and Electoral Institutions}

When the SNTV institution was in use to elect Lower House members, in most districts the district magnitude (the number of representatives elected from a given district) ranged from three and five, and the LDP typically fielded multiple candidates to garner a collective majority at the national level. These copartisan candidates typically divided their support base in terms of geography within the district (Tatebayashi 2004) and economic sectors (McCubbins and Rosenbluth 1995). In June 1993, a significant minority of LDP members left the LDP, and the party slipped out of power for the first time since its establishment in 1955. While the non-LDP coalition was in power for ten months, the 
government successfully installed a new hybrid electoral rule, which combined the SMD system and a proportional representation system.

As we discussed at the beginning of this article, since the LDP returned to power in June 1994, there has been a sequence of important changes in Japan's farm policy. We have also observed other important changes. Local branch offices of Nokyo are gradually being shut down after deregulation in the banking sector reduced Nokyo's profit margins in the nonfarm sector (Godo 1998). Furthermore, the Democratic Party of Japan (DPJ) has become increasingly popular among part-time farmers, but the party is now attracting more farm votes by proposing a new scheme of direct payment to farmers. ${ }^{10}$ The DPJ's suggested method of protection bypasses Nokyo and its network of clientelism.

Our argument is that these recent changes in Japan's farm policy are related to changes in electoral incentives. ${ }^{11}$ As detailed in the preceding section, rice farmers' incomes are highly dependent on both political discretion and exogenous shocks, especially natural disasters. When in desperate need of protection, farmers will seek politically generated income by campaigning for the governing party. The party will in turn provide policy benefits. The farmers' incentives for substitution between economic production and political activities, however, are conditional on electoral institutions. In an SNTV-MMD institution, the provision of selective benefits (or the available channels for delivery of benefits) is more elastic and proportional to the farmers' mobilization efforts, but in an SMD-based system, farmers have less motivation to work as campaigners if they expect that their additional efforts will not alter electoral outcomes.

In fact, the way that farmers campaign for the party has been changing since the electoral reform. An article in the Asahi Shimbun before the 2000 Lower House election exemplifies this transformation. Yawara Village in Ibaraki prefecture is a rural community in the northern outskirts of the greater Tokyo metropolitan area. In 1995, this village, with a population of about 15,000, had 1,155 farm households of which only sixty (about 5 percent) were full-time farmers. During the SNTV period, this district belonged to the Ibaraki third district, where four LDP incumbents were usually elected to fill five available seats. These LDP incumbents competed harshly with each other, and most of the village council members belonged to one of their koenkai (supporter groups). After the electoral reform, Yawara Village belonged to the Ibaraki sixth district, which became a safe seat for only one of the four former SNTV incumbents. The voter turnout in this village in the last SNTV election, in 1993, was 70.9 percent. In the first SMD elec- 
tion in 1996 , however, the turnout dropped sharply to 56.0 percent. One of the villagers lamented, "Voters are no longer interested in elections because they know that the incumbent will be a shoo-in even if we do nothing" (Asahi Shimbun, Ibaraki Edition, June 9, 2000).

\section{A Simple Model of Mobilization}

The following formal model succinctly summarizes the logic behind the change in the farmers' attitude toward electoral mobilization tactics. First, suppose that a homogenous group of Japanese part-time rice farmers in a given electoral district decides the allocation of their available time. Their utility is defined as $u\left(x_{r}, x_{v} \mid c\right)$, where $x_{r}$ is the amount of time spent on cultivating rice, and $x_{v}$ is the amount of time spent on cultivating votes-more specifically, mobilizing support for the governing party, which controls the provision of policy benefits. In the context of our empirical analysis, $x_{v}$ is the amount of time farmers devote to mobilizing support for an LDP candidate (or its coalition member). Given the fixed amount of time available to farmers, we can set $x_{v}=1-x_{r}$. We also assume that the level of utility is proportional to the farmers' annual incomes from these two activities. ${ }^{12}$

The exogenously given parameter $c$ depicts the crop condition of the season, where $c=c_{b}>0$ in bad seasons and $c=c_{g}>c_{b}$ in good seasons. ${ }^{13}$ It directly affects the marginal utility of farming, $\partial u / \partial x_{r}>0$ and $\partial u /$ $\left.\partial x_{r}\right|_{c=c g}>\partial u /\left.\partial x_{r}\right|_{c=c b}$, but given the time constraint, the crop condition also affects the time allocated for mobilization activities, as long as the marginal rate of substitution, MRS $=\left(\partial u / \partial x_{v}\right) /\left(\partial u / \partial x_{r}\right)$, which corresponds to the slope of an indifference curve, is not zero. Specifically, for any given positive value of MRS, farmers spend more time on lobbying activities when crop returns are (expected to be) lower. As we discussed previously, for a range of historical and political reasons, Japanese farmers-particularly, part-time farmers cultivating small rice fields - have become heavily dependent on political protection. Therefore, when their income is hit by exogenous factors, they have no choice but to seek political support for their own survival. ${ }^{14}$ This is the crux of the argument in our qualitative analysis in the earlier section on postwar agricultural politics in Japan.

Importantly, we assert that the extent to which voters seek political support when crops are damaged (formally, the size of MRS) depends on the property of electoral institutions. Under a proportional representation institution, the expected number of incumbents who represent farmers in a particular district is roughly proportional to the number of votes, which 
mirrors farmers' time spent on mobilization activities. For simplicity, we assume that the amount of political benefits-various selective benefits we discussed earlier, including pork barrel projects and programs-that a single incumbent can bring back home is constant. Therefore, as the number of incumbents increases (as the level of mobilization increases), farmers can expect a marginal increase in income from mobilization activities. To illustrate, suppose that the representative farmer's utility is a standard Cobb-Douglass function, $u=c \cdot \ln \left(1-x_{v}\right)+b \cdot \ln x_{v}$, where $b>0$ is the marginal productivity of mobilization. The optimal level of mobilization is $x_{v}^{*}=b /(b+c)$. This implies that as the marginal productivity of farming decreases due to bad conditions during a crop season (i.e., as the exogenous parameter $c$ decreases), the farmer spends more time on mobilization.

This marginal productivity of mobilization $b$ is not always positive (or assumed to be positive but smaller) under a simple-plurality rule with SMDs. This is because votes are translated into a seat in a discrete way. If farmers know that their preferred candidate already has a large number of loyal supporters who would collectively guarantee a seat in the next election, the expected marginal productivity of mobilization is near zero. In this situation, even when incomes derived from farming significantly decrease due to natural disasters, farmers cannot increase their incomes by participating in political activities. ${ }^{15}$ In the cited example of a Cobb-Douglass utility function, if $b \approx 0$, then $x^{*}{ }_{v} \approx 0$. The marginal rate of substitution is also near zero.

Empirically, our model predicts that the effect of damage to the rice crop on the optimal level of mobilization for government, which is proportional to the government party's vote share, can be positive and significant under the SNTV system with MMDs, which is one variant of a semiproportional system (Cox 1991). In an SMD system, however, this substitution mechanism does not always work.

An important note is that we do not necessarily assume that the marginal productivity of mobilization and the marginal rate of substitution have a fixed positive value in all MMDs and a zero value in all SMDs. In fact, it may be more reasonable, in theory, to assume that these parameters depend on the closeness of electoral competition. Empirically, however, we prefer to estimate the effects of crop damage on the government party's vote share with a simple dichotomous variable (i.e., SMD vs. MMD) for several reasons. First, and most importantly, our main interest lies in estimating the difference in the effect of exogenous shocks under different electoral institutions. Second, it is difficult to devise a measure that might allow us to compare competitive- 
ness in SMDs and MMDs in a valid manner, because both interparty and intraparty competition exist in MMD races and so should be taken into account when measuring closeness. In other words, competitiveness in SMDs (intraparty only) and competitiveness in MMDs (intraparty and interparty) may be conceptually different and thus a single indicator may not be a valid measure for both types of competitiveness. ${ }^{16}$

\section{Data and Variables}

To test the model developed in the previous section, we conduct fixedeffect regression analyses using data from both Lower House and Upper House elections during the postwar period in Japan. The unit of panel observations is prefecture by election year. Specifically, our data include prefecture-level aggregated results for the twenty-ninth (1958) to forty-fourth (2005) Lower House elections and fifth (1958) to twenty-first (2007) Upper House elections. ${ }^{17}$

The bicameral comparison using Japanese data provides the groundwork for examining how different electoral institutions affect political behavior by comparing observations across time and space (Cox, Rosenbluth, and Thies 2000). The Lower House elections used the SNTV rule with MMDs until the fortieth election in 1993. The number of seats in each district ranged from one to six, but most of the districts had three to five seats. ${ }^{18}$ After the electoral reform of 1994, all four subsequent elections were held under a hybrid system, which combines 300 SMDs and eleven regional blocs of proportional representation. ${ }^{19}$

Upper House elections in Japan have been conducted using an independent combination of prefecture-wide districts and a nationwide district. ${ }^{20}$ Approximately two-thirds of the Upper House legislators are elected from prefectural districts and the remaining third from a nationwide district. ${ }^{21}$ One notable feature of Japan's Upper House elections is that the prefectural districts consist of a mixture of SMDs and MMDs (with two to five seats).

The outcome variable is government coalition vote share, the number of votes for ruling parties divided by the number of valid votes cast (percent) ${ }^{22}$ In the Japanese context, this is almost identical to the LDP's vote share. To enhance the validity of our measure of the level of voter support for parties and individuals in the LDP-led government that support rice producers, however, we also include votes for those small parties that formed a coalition government with the LDP and any individuals who ran for office as "conservative independents" 
(hoshukei mushozoku). Although the latter were, in theory, not officially endorsed by any party at the time of the election, they were unofficially backed by one of the LDP factions. These independents almost always joined the LDP once they were elected to office.

The causal variable is rice damage ratio (RDR), which is the quantity of rice damage divided by the total quantity of rice damage and rice crop (percent). ${ }^{23}$ The rice damage includes reduced yields due to bad weather, blight, and insects. The denominator is equivalent to the normal quantity of rice crop (kijyun shukakuryo). The average ratio is about 4 percent, but it has a large variation within each prefecture, ranging from nearly 0 percent to almost 30 percent. This wide variation in the causal variable is a methodological advantage in estimating effect parameters in fixed-effect analysis.

Our theoretical model suggests that this variable has a significantly positive effect on the government-coalition vote share in MMDs but that these variables should have no significant relationship in SMDs. Thus, in our first set of regression models (Models 1 and 2), for each type of election (i.e., Lower House and Upper House election), we divide the observations into two groups-those with SMDs and those with MMDs-and separately estimate the effects of rice damage ratio on the government-coalition vote share. ${ }^{24}$ For the Lower House sample, we simply divide them into prereform years (1958-1993) and postreform years (1996-2005). The number of observations is 605 for the thirteen elections under the SNTV-MMD system and 188 for the four elections under the SMD system..$^{25}$ For the Upper House sample, we divide them based on the type of prefecture-level district. The number of observations is 355 in twenty-three prefectures with MMDs and 438 in thirty-two prefectures with SMDs. ${ }^{26}$

The rice crop damage's effects on electoral performance may be conditional not only on institutional environments but also on the size of the rice sector in each prefecture. The 10 percent crop damage should have larger effects in rice-growing prefectures (such as Niigata) than in urban prefectures with only limited rice production (such as Tokyo). To consider such heterogeneity in causal effects, we estimate another set of models (Models 3 and 4), which add agricultural workers ratio (AGR) - the number of workers in agriculture divided by the number of employed workers (percent) - and its interaction variable with rice damage ratio (RDR $\times$ AGR) to Models 1 and 2. ${ }^{27}$

A potential problem exists in comparing the effects of rice damage ratio by dividing observations: the difference in the level of significance between the SMD sample and the MMD sample may be due to the dif- 
ference in the number of observations in the two samples. Although this is less of an issue with Upper House results, it is a concern with Lower House results, because the number of observations is more than three times larger in MMD samples than in SMD samples (605 vs. 188).

To cope with this problem, Model 5 includes an SMD dummy $(\mathrm{SMD})$, and double- and triple-interaction variables: RDR $\times$ AGR, $\mathrm{RDR} \times \mathrm{SMD}, \mathrm{SMD} \times \mathrm{AGR}$, and RDR $\times \mathrm{SMD} \times \mathrm{AGR} .{ }^{28} \mathrm{~A}$ drawback of adding many interaction terms is that interpreting regression coefficient estimates become less straightforward. Thus, for Model 5, as well as double-interaction Models 3 and 4, we evaluate the marginal effect of rice damage ratio for each of the following twelve settings:

- Model $3(\mathrm{SMD}=0)$ : if the agricultural workers ratio (AGR) is 10 percent, 20 percent, or 30 percent

- Model $4(\mathrm{SMD}=1)$ : if the agricultural workers ratio (AGR) is 10 percent, 20 percent, or 30 percent

- Model 5: if the agricultural workers ratio (AGR) is 10 percent, 20 percent, or 30 percent and if SMD = 1

- Model 5: if the agricultural workers ratio (AGR) is 10 percent, 20 percent, or 30 percent and if SMD $=0$

We compute a point estimate and its standard error for each linear combination of coefficients after estimation. ${ }^{29}$

To improve the validity of our causal estimate as much as possible, we also consider other possible explanatory factors. At a minimum, we need to add prefecture-specific fixed effects and control for a number of time-invariant prefecture-specific geographical, topological, meteorological, demographic, economic, political, and cultural factors. Clearly, the location does matter in our analysis, because it should correlate with the likelihood of natural disasters and the unobservable, underlying (long-term) political preferences of voters. We also add election-year dummies. These year-specific effects should control national swings in the distribution of votes across political parties, as well as technological changes that might prevent damage to rice from natural disasters.

Acreage per farmer, the amount of land devoted to planting rice divided by the number of workers in agricultural sectors (in log), is the key variable to understanding postwar agricultural politics in Japan. ${ }^{30}$ As we discussed in the section on postwar agricultural politics, in the Japanese context, small-scale farmers are typically politically protected, part-time, inefficient rice farmers, who may not take sufficient 
measures to reduce disaster effects to a minimum. Thus, this variable should correlate with both the causal and outcome variables.

In addition, we add a set of proxies for the degree of protection to agricultural sectors. If a given prefecture's agriculture is highly protected, farmers may face an incentive to shirk their efforts to prevent crop damage while strongly supporting the incumbent government. In the context of the Japanese political economy, highly protected prefectures are overrepresented with a smaller number of seats per voter (Horiuchi and Saito 2003, in log), prefectures with small population (in $\log$ ), prefectures with fewer urban areas or smaller DID (densely inhabited district) population ratio (percent), prefectures with larger aged population ratio (percent), and prefectures with larger agricultural workers ratio (percent). ${ }^{31}$ Existing studies of Japanese politics and economy (e.g., Doi and Ashiya 1997; Horiuchi and Saito 2003; Ihori and Doi 1998) suggest that these variables are strong predictors of the LDP's electoral performance. We expect, however, that they are uncorrelated with rice damage, which is determined largely by exogenous shocks. Therefore, adding these variables in our fixed-effect analysis should not drastically change the magnitude of the coefficient for our causal variable.

\section{Results}

The results of the fixed-effect regressions are shown in Table 1 (Lower House) and Table 2 (Upper House). We first look at Lower House results. Model 1 shows that the effect of the rice damage ratio is positive (estimated coefficient $=0.25$ ) and significant at 1 percent in the MMD sample. If the rice damage ratio changes by two standard deviations $(3.85 \times 2)$, the government-coalition vote share increases by 1.6 percentage points. This is a considerably large effect, given that we control all prefecture-specific and year-specific effects, as well as six other control variables. In the SMD sample (Model 2), the effect is positive (estimated coefficient $=0.17$ ) but insignificant. The magnitude of the effect is smaller than in the SMD sample. These results are consistent with our expectation. Models 1 and 2 in Upper House results (Table 2) show that the effect of the rice damage ratio is positive but insignificant in the MMD sample. In the SMD sample, it is also insignificant and even negative. The results do not necessarily support our hypothesis. We come back to this difference after discussing the results of the other models. 
Table 1 Fixed-Effect Regression Results, Lower House

\begin{tabular}{lccccc}
\hline Model & 1 & 2 & 3 & 4 & 5 \\
& MMD & SMD & MMD & SMD & Both \\
\hline Rice damage ratio (\%, RDR) & $0.25^{* * *}$ & 0.17 & 0.20 & 0.10 & 0.13 \\
& $(0.09)$ & $(0.20)$ & $(0.18)$ & $(0.44)$ & $(0.16)$ \\
Agricultural workers ratio (\%, AGR) & -0.07 & 1.62 & -0.08 & 1.47 & -0.09 \\
& $(0.09)$ & $(1.95)$ & $(0.10)$ & $(2.15)$ & $(0.10)$ \\
Acreage per farmer (ln) & -0.02 & -20.05 & -0.08 & -20.29 & $-3.04^{*}$ \\
& $(1.46)$ & $(12.60)$ & $(1.48)$ & $(12.25)$ & $(1.69)$ \\
Number of seats per vote (ln) & 0.06 & 7.77 & -0.05 & 7.96 & $8.03^{*}$ \\
& $(7.30)$ & $(6.80)$ & $(7.29)$ & $(6.97)$ & $(4.52)$ \\
Population (ln) & $-0.18^{* *}$ & $1.30^{* * *}$ & $-0.19 * *$ & $1.30^{* * *}$ & $-0.17 * *$ \\
& $(0.07)$ & $(0.34)$ & $(0.07)$ & $(0.35)$ & $(0.07)$ \\
Aged population ratio (\%) & -0.38 & $3.75^{*}$ & -0.41 & $3.81^{*}$ & -0.32 \\
& $(0.90)$ & $(2.19)$ & $(0.90)$ & $(2.21)$ & $(0.77)$ \\
DID population ratio (\%) & -0.14 & -0.58 & -0.14 & -0.59 & 0.09 \\
& $(0.11)$ & $(1.32)$ & $(0.11)$ & $(1.34)$ & $(0.13)$ \\
RDR x AGR & & & 0.00 & 0.01 & 0.01 \\
& & & $(0.01)$ & $(0.04)$ & $(0.01)$ \\
RDR x SMD & & & & & -0.48 \\
& & & & & $(0.44)$ \\
SMD x AGR & & & & & $\left(0.75^{*}\right.$ \\
& & & & & 0.03 \\
RDR x SMD x AGR & & & & & $(0.04)$ \\
\hline Number of observations & 605 & 188 & 605 & 188 & 793 \\
Number of groups (prefectures) & 47 & 47 & 47 & 47 & 47 \\
R-sq: within & 0.45 & 0.26 & 0.45 & 0.26 & 0.36 \\
R-sq: between & 0.48 & 0.29 & 0.48 & 0.29 & 0.35 \\
R-sq: overall & 0.45 & 0.19 & 0.45 & 0.19 & 0.34 \\
\hline
\end{tabular}

Note: The dependent variable is the government coalition vote share (percent). All models include prefecture fixed effects and election-year fixed effects. Robust clustered standard errors are in parentheses, where clusters are prefectures. Models 2 and 4 include four postreform elections (1996, 2000, 2003, 2005; single-member districts), while Models 1 and 3 include prereform elections (1958-1993; multimember districts). Model 5 includes all elections. In Model 5 , SMD dummy is dropped due to perfect multicollinearity with election fixed effects.

$*$ significant at $10 \% ; * *$ significant at $5 \% ; * * *$ significant at $1 \%$

Models 3, 4, and 5 are interaction models, and the results of postestimation interpretation given various settings are presented in Table 3. The results are essentially similar to those based on baseline Models 1 and 2, but they also show the expected heterogeneity in the effects of the crop damage ratio in the Lower House results. Specifically, the effects of the crop damage ratio on the governing party's vote share in Lower House elections are all positive and, more importantly, the magnitude of the effects become larger as the agricultural workers ratio increases. Model 5, a triple-interaction model using all observations, shows that the estimated coefficients are 0.19 (if agricultural workers 
Table 2 Fixed-Effect Regression Results, Upper House

\begin{tabular}{|c|c|c|c|c|c|}
\hline Model & $\begin{array}{c}1 \\
\text { MMD }\end{array}$ & $\begin{array}{c}2 \\
\text { SMD }\end{array}$ & $\begin{array}{c}3 \\
\text { MMD }\end{array}$ & $\begin{array}{c}4 \\
\text { SMD }\end{array}$ & $\begin{array}{c}5 \\
\text { Both }\end{array}$ \\
\hline Rice damage ratio (\%, RDR) & $\begin{array}{c}0.17 \\
(0.21)\end{array}$ & $\begin{array}{c}-0.10 \\
(0.14)\end{array}$ & $\begin{array}{c}0.36 \\
(0.28)\end{array}$ & $\begin{array}{c}-0.23 \\
(0.20)\end{array}$ & $\begin{array}{c}0.25 \\
(0.30)\end{array}$ \\
\hline Agricultural workers ratio (\%, AGR) & $\begin{array}{c}-0.13 \\
(0.14)\end{array}$ & $\begin{array}{c}-0.15 \\
(0.19)\end{array}$ & $\begin{array}{c}-0.07 \\
(0.17)\end{array}$ & $\begin{array}{c}-0.17 \\
(0.18)\end{array}$ & $\begin{array}{c}-0.01 \\
(0.16)\end{array}$ \\
\hline Acreage per farmer $(\ln )$ & $\begin{array}{c}-2.28 \\
(1.86)\end{array}$ & $\begin{array}{l}5.88^{* * *} \\
(2.50)\end{array}$ & $\begin{array}{c}-2.15 \\
(1.97)\end{array}$ & $\begin{array}{l}5.77 * * \\
(2.49)\end{array}$ & $\begin{array}{c}0.26 \\
(2.05)\end{array}$ \\
\hline Number of seats per vote $(\ln )$ & $\begin{array}{c}5.60 \\
(4.26)\end{array}$ & $\begin{array}{c}5.00 \\
(31.07)\end{array}$ & $\begin{array}{c}6.03 \\
(4.24)\end{array}$ & $\begin{array}{c}4.17 \\
(30.28)\end{array}$ & $\begin{array}{c}4.91 \\
(4.32)\end{array}$ \\
\hline Population (ln) & $\begin{array}{c}-0.11 \\
(0.13)\end{array}$ & $\begin{array}{c}-0.14 \\
(0.25)\end{array}$ & $\begin{array}{c}-0.10 \\
(0.13)\end{array}$ & $\begin{array}{c}-0.15 \\
(0.25)\end{array}$ & $\begin{array}{c}-0.01 \\
(0.09)\end{array}$ \\
\hline Aged population ratio (\%) & $\begin{array}{c}-1.83 \\
(1.35)\end{array}$ & $\begin{array}{c}-0.57 \\
(0.88)\end{array}$ & $\begin{array}{c}-1.82 \\
(1.34)\end{array}$ & $\begin{array}{c}-0.62 \\
(0.89)\end{array}$ & $\begin{array}{c}-0.64 \\
(0.72)\end{array}$ \\
\hline DID population ratio $(\%)$ & $\begin{array}{c}-0.12 \\
(0.25)\end{array}$ & $\begin{array}{c}-0.27 \\
(0.18)\end{array}$ & $\begin{array}{c}-0.15 \\
(0.26)\end{array}$ & $\begin{array}{c}-0.27 \\
(0.18)\end{array}$ & $\begin{array}{c}-0.35^{* *} \\
(0.16)\end{array}$ \\
\hline SMD dummy (SMD) & & & & & $\begin{array}{c}5.75^{*} \\
(3.24)\end{array}$ \\
\hline RDR $\times$ AGR & & & $\begin{array}{c}-0.01 \\
(0.02)\end{array}$ & $\begin{array}{c}0.01 \\
(0.01)\end{array}$ & $\begin{array}{c}-0.01 \\
(0.02)\end{array}$ \\
\hline $\mathrm{RDR} \times \mathrm{SMD}$ & & & & & $\begin{array}{c}-0.58 * * \\
(0.28)\end{array}$ \\
\hline SMD $\times$ AGR & & & & & $\begin{array}{c}-0.15 \\
(0.11)\end{array}$ \\
\hline $\mathrm{RDR} \times \mathrm{SMD} \times \mathrm{AGR}$ & & & & & $\begin{array}{c}0.03^{*} \\
(0.02)\end{array}$ \\
\hline Number of observations & 355 & 438 & 355 & 438 & 793 \\
\hline Number of groups (prefectures) & 23 & 32 & 23 & 32 & 47 \\
\hline R-sq: within & 0.30 & 0.36 & 0.30 & 0.36 & 0.31 \\
\hline R-sq: between & 0.67 & 0.01 & 0.67 & 0.01 & 0.60 \\
\hline R-sq: overall & 0.50 & 0.16 & 0.51 & 0.16 & 0.42 \\
\hline
\end{tabular}

Note: The dependent variable is the government coalition vote share (percent). All models include prefecture fixed effects and election-year fixed effects. Robust clustered standard errors are in parentheses, where clusters are prefectures. Models 2 and 4 include MMD (multimember district) observations, while Models 1 and 3 include SMD (single-member district) observations. Model 5 includes all observations.

* significant at $10 \%$; ${ }^{*}$ significant at $5 \%$; $* *$ significant at $1 \%$

ratio is 10 percent, not significant), 0.25 (if it is 20 percent, significant at 1 percent), and 0.31 (if it is 30 percent, significant at 1 percent) if the SMD dummy is zero (for MMD observations). If the SMD dummy is one, the magnitude of the effects increases as the agricultural workers ratio increases (from -0.04 to 0.27 , and then to 0.58 ), but the estimates are all statistically insignificant. Models 3 and 4, which use the MMD sample and the SMD sample separately, also produce similar estimates. These results are consistent with our expectations.

Analysis of Upper House elections using the same set of interaction models again shows results that are not consistent with what we 
Table 3 Marginal Effects of Rice Damage Ratio

\begin{tabular}{|c|c|c|c|c|c|c|}
\hline \multirow[b]{2}{*}{ Model } & \multirow[b]{2}{*}{ SMD } & \multirow[b]{2}{*}{$\operatorname{AGR}(\%)$} & \multicolumn{2}{|c|}{ Lower House } & \multicolumn{2}{|c|}{ Upper House } \\
\hline & & & Coefficient & $\begin{array}{l}\text { Standard } \\
\text { Error }\end{array}$ & Coefficient & $\begin{array}{c}\text { Standard } \\
\text { Error }\end{array}$ \\
\hline 3 & No & 10 & $0.22 *$ & $(0.12)$ & 0.23 & $(0.20)$ \\
\hline 3 & No & 20 & $0.25^{* * *}$ & $(0.09)$ & 0.09 & $(0.26)$ \\
\hline 3 & No & 30 & $0.27 * * *$ & $(0.09)$ & -0.05 & $(0.39)$ \\
\hline 4 & Yes & 10 & 0.18 & $(0.20)$ & -0.16 & $(0.14)$ \\
\hline 4 & Yes & 20 & 0.25 & $(0.44)$ & -0.09 & $(0.14)$ \\
\hline 4 & Yes & 30 & 0.32 & $(0.81)$ & -0.03 & $(0.20)$ \\
\hline 5 & No & 10 & 0.19 & $(0.12)$ & 0.12 & $(0.21)$ \\
\hline 5 & No & 20 & $0.25^{* * *}$ & $(0.09)$ & -0.01 & $(0.24)$ \\
\hline 5 & No & 30 & $0.31 * * *$ & $(0.10)$ & -0.14 & $(0.35)$ \\
\hline 5 & Yes & 10 & -0.04 & $(0.14)$ & -0.17 & $(0.13)$ \\
\hline 5 & Yes & 20 & 0.27 & $(0.44)$ & -0.01 & $(0.13)$ \\
\hline 5 & Yes & 30 & 0.58 & $(0.84)$ & 0.16 & $(0.18)$ \\
\hline
\end{tabular}

Note: All other variables are held constant at their means. SMD $=$ single-member district, $\mathrm{AGR}=$ agricultural workers ratio.

$*$ significant at $10 \% ; * *$ significant at $5 \%$; *** significant at $1 \%$

expected. All of the estimated coefficients are insignificant at the conventional level. The magnitude of these coefficients tends to be smaller than those in the Lower House results, and can be even negative.

So why then does crop damage lead to a statistically significant higher level of support for LDP incumbents in Lower House elections but not in Upper House elections? One possible answer lies in an institutional feature that makes the Lower House distinct from the Upper House-the constituency size is considerably larger in the Upper House than in the Lower House. For example, in 1993, when the last Lower House election using the SNTV rule was conducted, the per legislator constituency size was 181,296. In 1996, when the first Lower House election using the SMD-PR rule was conducted, the mean constituency size per legislator in the SMD portion was 325,602 . In contrast, because only half of its seats are up for election every three years, the mean per-legislator constituency size in the Upper House district portion was $1,127,468$ in 1995 . This implies that the number of voters that rice farmers need to mobilize to get their favorable candidate elected is much larger in Upper House elections than in Lower House elections. Even when a rice crop is hard hit, farmers may not make any additional effort to mobilize votes for candidates in an Upper House election. Accordingly, the insignificant Upper House results may not necessarily refute our hypothesis. Rather, it may strengthen our bot- 
tom-line argument: farmers seek political protection only when the amount of rents they extract is expected to be commensurate with their efforts.

\section{Robustness Check}

There remain two potential criticisms of our analysis and interpretation. First, our formal model assumes that what matters in translating crop damage to electoral outcomes is how much an additional mobilization affects election results and the competitiveness of a particular electoral race. As a result, our use of a simple dichotomy (SMD or MMD) may not be an appropriate measure of the conceptual variable of theoretical interest. Second, since the 1994 electoral reform of the Lower House and the 1994 adoption of the Uruguay Round Agreement on Agriculture took place almost in the same year, the estimated difference for the Lower House results may not reflect the difference in incentive structures under the SNTV-MMD system and the SMD-dominant hybrid system.

Given this potential criticism, we conducted a robustness check using a variable that can be an alternative to the simple MMD vs. SMD dichotomy. Specifically, we used the number of candidates divided by the number of seats in each prefecture, $(M+v) / M$ where $M$ is the number of seats and $v$ is greater than or equal to 1 . We assume that the smaller the value this variable is, the more competitive the district race becomes. Let us explain the rationale underlying this assumption.

In an important article on how to measure closeness in multimember districts, Steven Reed and Kay Shimizu (2007) coded all candidates into categories of "safe" candidates, "token" candidates who have no chance of winning, and "cusp" candidates who may win or lose depending on voters' responses to campaigns. They then proposed to use the number of cusp candidates in each district as an alternative measure of a district's competitiveness. Using the MMD sample from Japan, they found that the distribution of cusp candidates was bimodal. The MMD districts tended to be noncompetitive (i.e., the number of cusp candidates is zero) or fully competitive (i.e., all $M+1$ candidates are cusp candidates).

This important finding implies the following. First, if there are $M$ +1 candidates, as the number of seats increases, the district tends to be more competitive. Second, if there are $M+v$ candidates (where $v>1$ ), votes between potentially cusp and token candidates are divided and thus the number of cusp candidates tends to decrease. Namely, the number of cusp candidates tends to converge toward zero as the number of candidates increases. Therefore, a combination of these two im- 
plications suggests that as $(M+v) / M$ where $v \geq 1$ decreases, the district tends to be more competitive.

Clearly, this is not a direct measure of competitiveness. As we argued at the end of the section on electoral systems and agricultural protectionism, it is not straightforward to develop a single valid measure for competitiveness in both SMD and MMD races. ${ }^{32}$ Nevertheless, we believe that this simple measure can serve our purpose as a robustness check for two reasons. First, Reed and Shimizu's (2007) analysis suggests that it can be a proxy for competitiveness. Second, although the SMD dummy for Lower House results is strongly correlated with the timing of the international agriculture agreement, the number of candidates divided by the number of seats is not.

Using this alternative measure $(M+v) / M$, we ran Model 5 using the Lower House data. The alternative measure ranges from 1.2 to 5.8 (the mean $=2.2$ ), and we evaluated the marginal effects of the crop damage ratio when it is $1.5,2.5$, and 3.5 and, for each case, when the agricultural workers ratio (AGR) is 10,20 , and 30 percent. The results of postestimation analysis for these nine scenarios, as presented in Table 4, support our argument. ${ }^{33}$ As the level of competitiveness increases (i.e., as $(M+v) / M$ decreases), the effects of the crop damage ratio tend to be more significant. Furthermore, as the agricultural workers ratio increases, the crop damage ratio tends to have larger effects. These patterns suggest that competitiveness affects farmers' voting behavior. With these results, it is difficult to interpret the estimated difference between SMDs and MMDs in the Lower House results as sim-

Table 4 Results of Robustness Check

\begin{tabular}{cccc}
\hline$(M+v) / M$ & AGR $(\%)$ & Coefficient & Standard Error \\
\hline 1.5 & 10 & $0.22^{*}$ & 0.12 \\
1.5 & 20 & $0.28^{* * *}$ & 0.09 \\
1.5 & 30 & $0.34^{* *}$ & 0.14 \\
2.5 & 10 & 0.09 & 0.08 \\
2.5 & 20 & $0.19^{* *}$ & 0.08 \\
2.5 & 30 & $0.30^{* *}$ & 0.13 \\
3.5 & 10 & -0.04 & 0.10 \\
3.5 & 20 & 0.11 & 0.16 \\
3.5 & 30 & 0.26 & 0.30 \\
\hline
\end{tabular}

Note: Model 5 is applied to the Lower House data. All other variables are held constant at their means. $(M+v) / M=$ the number of candidates divided by the number of seats, AGR $=$ agricultural workers ratio.

$*$ significant at $10 \% ; * *$ significant at $5 \%$;** significant at $1 \%$ 
ply reflecting the fact that both electoral reform and the international agricultural agreement took place in roughly the same period.

\section{Conclusion}

In this article, using data from Japan, we have shown that in Lower House elections, crop damage had an effect on the governing party's vote share in MMDs but not in SMDs. Our robustness test, as well as our formal model, suggests that different levels of competitiveness under different electoral systems influence the way farmers seek politically generated incomes during hard times and campaign for the party in power. The configuration of domestic institutions and its impact on behaviors of farmers has a nontrivial implication for the direction of farm protectionism (and hence trade policy) a country pursues. Previous studies of the impact of political institutions on trade policies, however, have underinvestigated this important dimension. We believe that, in order to improve our understandings of the origins of agricultural protectionism, future research ought to shed light on interactions between both demanders and suppliers of protective measures in various institutional contexts.

The findings also imply that Japan's peculiar farm policy, which has provided intensive protection to small inefficient farms of a single commodity, is, at least in part, a product of the SNTV-MMD rule. Therefore, the introduction of a new SMD-based hybrid system is relevant to the gradual transition of Japan's farm policy into the type of producer-support policy more commonly seen among other OECD countries. As we have shown in this article, the inelastic response of rewards to farmers' mobilization efforts weakened the way farmers' demands are reflected in electoral outcomes.

Yusaku Horiuchi is associate professor in the Crawford School of Economics and Government at the Australian National University. His research interests include electoral systems, distributive politics, public opinion, Japanese politics, and research methods. He is author of Institutions, Incentives and Electoral Participation in Japan (2005) and has published articles in American Journal of Political Science, Journal of Politics, British Journal of Political Science, Journal of Conflict Resolution, and others.

Jun Saito is assistant professor in the Department of Political Science at Yale University. He earned his $\mathrm{PhD}$ in political science from Yale University in May 2006. His research focuses on the institutional determinants of representation and redistribution. At Yale, he teaches courses on Japanese politics, 
Japan's foreign policy, and comparative capitalism in East Asia. His research has appeared in American Journal of Political Science, Asian Survey, Journal of East Asian Studies, and others.

\section{Notes}

Earlier versions of this article were presented at the annual meeting of the Association for Asian Studies, April 3-6, 2008; the Workshop on Elections and Distribution (University of California, San Diego), April 18-19, 2008; the 2008 annual meeting of the American Political Science Association, August 28-31, 2008; and the Economics and Democracy Conference (Australian National University), December 8-10, 2008. We appreciate useful comments from Christina Davis, Shigeo Hirano, Megumi Naoi, and Steven Reed, participants in those conferences, and from anonymous reviewers. Please send all correspondence to Horiuchi (yusaku.horiuchi@ anu.edu.au).

1. For comprehensive studies of Japan's agricultural politics and political economy, see a series of books by George-Mulgan (2000, 2005, 2006).

2. As of mid-2008, the government was deterring rice imports into the Japanese market by an effective tariff rate of 780 percent (Asahi Shimbun, July $31,2008)$.

3. One exception is a recent study by Ehrlich (2007), which examines how different political institutions lead to differing levels of lobbying costs.

4. Campaign contribution data are available for recent years (Sasaki et al. 1999), but their coverage and quality is too limited to serve our research purposes.

5. Our empirical results show that the effects on the government coalition's vote share in Upper House elections are statistically insignificant in both MMDs and SMDs. We discuss possible reasons for the difference between the Lower House results and the Upper House results.

6 . Therefore, it is unreasonable to assume that farmers are passively waiting for assistance from the government during crises and that the estimated effect of crop damage on electoral results is a consequence of changes in incentives and behavior of the government - the supply side of protection. Also see George-Mulgan (2000) for a discussion of why Japanese farmers have become so politically dependent.

7. It is worth noting that the target of the LDP's generous farm policy has been limited to rice farmers. For example, one of the observable consequences of overprotection is stagnant productivity growth. Between 1955 and 1995, the number of pigs and chickens per farm increased about 350 times or 35,000 percent, but per-farm acreage of rice in the same period increased only 30 percent (Hayami and Godo 2002, 264). In 2002, only 37 percent of rice farmers generated their primary income from farming, compared to 83 percent of vegetable farmers and 96 percent of dairy farmers (Norin Suisansho 2004).

8 . The labor union density of nonfarm workers in Japan was about 35 percent at its peak in the 1970s (Rodosho 1975), whereas the number of Nokyo 
members remained larger than the number of farmers. This is because of a near 100 percent membership participation rate among farmers and a large number of retired farmers who depended on Nokyo's financial services and real estate business (Uchida 2002).

9. On occasion, Nokyo tried to increase its profit margins by investing farmers' deposits in nonagricultural sectors, which was outside the scope of banking regulations administered by the Ministry of Finance. In 1996, lax investment of the Nokyo money triggered the jusen (housing loan companies) problems or the Japanese predecessor of the subprime crisis (Saeki 1997).

10. With the landslide victory in the 2007 Upper House and 2009 Lower House elections, the DPJ became the largest party in both houses in the Japanese Diet and has occupied current coalition government since September 2009. It is worth examining agricultural politics and policymaking under the new government, but this is beyond the scope of this article.

11. Another possible argument, which we noted in the introductory section, is that the changes reflect the adoption of the Uruguay Round Agreement on Agriculture in 1994. We argue against this possibility in a later section with the results of statistical analysis.

12. We assume that the cost of spending a unit time for either activity is constant. Therefore, the farmers can maximize their utility when their indifference curve is tangent to an isocost line whose slope is minus one.

13. As we detailed in the previous section, producer prices of rice are politically determined, and fluctuations in rice grain yields do not affect perquantity prices of rice. In this sense, the crop damage in quantity directly translates into a loss of farmers' income.

14. Voluminous studies on economic voting suggest that voters punish, rather than reward, incumbents when the economy is bad (e.g., see Lewis-Beck and Stegmaier 2000 for a review). Recent natural experimental studies also suggest that voters punish the incumbent party for bad events beyond its control (Achen and Bartels 2004; Healy 2008; Leigh 2009). A recent study by Cole, Healy, and Werker (2008) shows, however, that voters' negative responses can be mitigated depending on how vigorously the incumbent party responds to the crisis. We feel that our Japanese case is exactly the one that supports their view.

15. Note that we assume, for simplicity, that the number of pork barrel projects a governing party delivers is proportional to the number of elected incumbents per voter. In reality, in MMDs under the SNTV institution, intraparty competition among multiple co-partisan incumbents provides added pressures for delivering pork barrel spending to local communities. Imposing this realistic assumption does not invalidate our argument that farmers are more motivated to mobilize votes (when crop conditions are bad) in MMDs than SMDs.

16. Having recognized this problem, however, we conduct a robustness check with a proxy variable for the closeness of electoral competition. The results are discussed in the Results section.

17. We use prefecture-level data because our causal variable is only available at this level. We do not include the 2009 Lower House elections, mainly 
because most recent crop-related statistics are unavailable as of this writing. Since the LDP suffered the historical defeat, we intend to conduct a further study on how farmers voted in the 2009 elections. Also see note 10.

18. One of the districts in Kagoshima prefecture (the Amami Gunto district) had a single seat from the 1953 to 1990 Lower House elections. Since we use data aggregated at the prefecture level, we ignore this minor exception.

19. The total district magnitude of the eleven proportional representation (PR) regional blocs was 200 in the 1996 election and 180 thereafter. Given this larger share of the SMD portion and the fact that most PR candidates from major parties also run from SMDs and their list ranking is also determined by their SMD vote share, Japan's new hybrid rule is basically an SMD-dominant system.

20. Unlike the hybrid system of the German Bundestag, the vote share of one portion does not affect the seat allocation of the other in the Japanese hybrid system. Note that these prefecture-level elections use the SNTV rule.

21. The members of the Upper House serve the fixed six-year term, and half the seats in the Upper House elections come up for election every three years. In the nationwide portion, which is not our focus in this article, a nationwide SNTV district system was used until the 1980 election, which was replaced by a closed-list PR in 1983. The nationwide PR portion was modified into an open-list system in 2001.

22. The data sources for Lower House election results are Asahi Shimbun (2003, 2005) and Mizusaki (1993, 1996, 2000). Upper House election results are based on Jichisho (various years).

23. The data are adopted from Norin Suisansho (various years). We use the mean annual damage during interelection years, assuming that farmers' mobilization efforts are affected by multiple rounds of damage-mobilization cycles.

24. All models estimate clustered robust standard errors where clusters are prefectures.

25. There were forty-six prefectures (excluding Okinawa) before 1971.

26. They include seventeen elections in forty-seven prefectures (forty-six prefectures, excluding Okinawa from fifth to ninth Upper House elections). Among the forty-seven prefectures, twenty-four prefectures have had a single seat in all the Upper House elections held throughout the postwar period, and fifteen prefectures have had two or more seats in all the elections. The remaining eight prefectures had SMDs or MMDs.

27. The data source for agricultural workers ratio is Somusho Tokeikyoku (various years).

28. The SMD dummy is dropped in the analysis of Lower House elections, because it is perfectly correlated with election-year fixed effects. Interaction variables are, however, not dropped because they are time variant.

29. We use the lincom command of STATA ver. 11.

30. The data sources are the same as rice damage. As with our causal variable, we use the average between two election years.

31. The data sources are Somusho Tokeikyoku (various years). Note that in all models, we also include agricultural workers ratio as a control, in addition to 
its interaction term with crop damage ratio. For the convenience of presenting coefficient estimates, we multiply the logged value of population size by 100 .

32. Technically, it is possible to measure Reed and Shimizu's proposed variable (i.e., the number of cusp candidates per district) for SMDs, but it is not clear whether it can be used to compare the nature of competitiveness in SMDs and that in MMDs, because, as we argued, the competition in MMDs contains not only interparty competition but also intraparty competition.

33. The regression result table is available upon request to authors.

\section{References}

Achen, Christopher H., and Larry M. Bartels. 2004. "Blind Retrospection: Electoral Responses to Drought, Flu, and Shark Attacks." Manuscript.

Asahi Shimbun. 2003. Asahi.com de Miru 2003 Sosennkyo no subete [Everything about the 2003 general election as seen at Asahi.com]. Tokyo: Asahi Shimbun.

- 2005. Asahi.com de Miru 2005 Sosennkyo no subete [Everything about the 2005 general election as seen at Asahi.com]. Tokyo: Asahi Shimbun.

Cole, Shawn A., Andrew Healy, and Eric D. Werker. 2008. "Do Voters Appreciate Responsive Governments? Evidence from Indian Disaster Relief." Manuscript.

Cox, Gary W. 1987. The Efficient Secret: The Cabinet and the Development of Political Parties in Victorian England. Cambridge: Cambridge University Press.

- 1991. "SNTV and d'Hondt Are 'Equivalent."” Electoral Studies 10, 2: $118-132$.

Cox, Gary W., Frances M. Rosenbluth, and Michael F. Thies. 2000. "Electoral Rules, Career Ambitions, and Party Structure: Comparing Factions in Japan's Upper and Lower Houses." American Journal of Political Science 44, 1: 115-122.

Curtis, Gerald L., and Masumi Ishikawa. 1983. Doken kokka nippon: Sekai no yutosei no tsuyomi to yowami [Contractor state Japan: The strength and weakness of the world's economic power]. Tokyo: Kobunsha.

Davis, Christina, and Jennifer Oh. 2007. "Repeal of the Rice Laws in Japan: The Role of International Pressure to Overcome Vested Interests." Comparative Politics 40, 1: 21-40.

Doi, Takero, and Masahiro Ashiya. 1997. "Kokko shishutsukin bunpai to seiken yoto no kankei" [The relationship between the distribution of subsidies from the central government to municipalities and the governing party]. Nihon Keizai Kenkyu 34: 180-194.

Ehrlich, Sean D. 2007. "Access to Protection: Domestic Institutions and Trade Policy in Democracies.” International Organization 61, 3: 571-605. 
Fukui, Haruhisa, and Shigeko N. Fukai. 1996. "Pork Barrel Politics, Networks, and Local Economic Development in Contemporary Japan." Asian Survey 36, 3: 268-286.

George-Mulgan, Aurelia. 2000. The Politics of Agriculture in Japan. London: Routledge.

2005. Japan's Interventionist State: The Role of the MAFF. London: Routledge.

- 2006. Japan's Agricultural Policy Regime. London: Routledge.

Godo, Yoshihisa. 1998. "Nokyo mondai no seiji keizaigaku" [Political economy of the Nokyo problem]. In Nogyo mondai no seiji keizai bunseki [Politico-economic analysis of agricultural policy issues], ed. Masayoshi Honma and Masahiro Okuno. Tokyo: Nihon Keizai Shinbunsha.

Grampp, William D. 1987. "How Britain Turned to Free Trade." The Business History Review 61, 1: 86-112.

Haley, John Owen. 2008. "Rivers and Rice: What Lawyers and Legal Historians Should Know About Medieval Japan." Manuscript.

Hayami, Yujiro. 1991. "Institutional Aspects of Agricultural Development." In The Agricultural Development of Japan: A Century's Perspective, ed. Yujiro Hayami and Saburo Yamada. Tokyo: University of Tokyo Press.

Hayami, Yujiro, and Yoshihisa Godo. 2002. Nogyo keizairon [Agricultural economics], 2nd ed. Tokyo: Iwanami.

Hayami, Yujiro, and Toshihiko Kawagoe. 1991. "Farm Mechanization, Scale Economies, and Structural Change." In The Agricultural Development of Japan: A Century's Perspective, ed. Yujiro Hayami and Saburo Yamada. Tokyo: University of Tokyo Press.

Healy, Andrew. 2008. "Do Voters Punish Politicians for Bad Luck? The Uneducated Ones Do." Manuscript.

Hirose, Michisada. 1981. Hojokin to seikento [Subsidies and the governing party]. Tokyo: Asahi Shimbunsha.

Honma, Masayoshi, Aurelia George-Mulgan, and Yoshihisa Godo. 2004. "Nihon nogyo no kokusaika to seiji nokyo no kaikaku" [Internationalization of Japanese agriculture and reform of politics and Nokyo]. Discussion Paper Series. Tokyo: Research Institute of Economy, Trade, and Industry.

Horiuchi, Yusaku. 2005. Institutions, Incentives, and Electoral Participation in Japan: Cross-Level and Cross-National Perspectives. London: Routledge.

Horiuchi, Yusaku, and Jun Saito. 2003. "Reapportionment and Redistribution: Consequences of Electoral Reform in Japan." American Journal of Political Science 47, 4: 669-682.

Ihori, Toshihiro, and Takero Doi. 1998. Nihon seiji no keizai bunseki [Economic analysis of Japanese politics]. Tokyo: Bokutakusha.

Ishikawa, Masumi. 1999. Ochiteiku seiji [Corrupting politics]. Tokyo: Iwanami.

Jichisho [Ministry of Home Affairs, Department of Elections]. Various years. Sangiin giin tsuju senkyo kekka shirabe [The results of election of the House of Councillors]. Tokyo: Jichisho.

Karol, David. 2007. 'Does Constituency Size Affect Elected Officials' Trade Policy Preferences?” Journal of Politics 69, 2: 483-494. 
Leigh, Andrew. 2009. "Does the World Economy Swing National Elections?" Oxford Bulletin of Economics and Statistics 71, 2: 163-181.

Lewis-Beck, Michael S., and Mary Stegmaier. 2000. "Economic Determinants of Electoral Outcomes." Annual Review of Political Science 3: 183-219.

McCubbins, Mathew D., and Frances M. Rosenbluth. 1995. "Party Provision for Personal Politics: Dividing the Vote in Japan." In Structure and Policy in Japan and the United States, ed. Peter F. Cowhey and Mathew D. McCubbins. New York: Cambridge University Press.

McDonald, Mary G. 1996. "Farmers as Workers in Japan's Regional Economic Restructuring.” Economic Geography 72, 1: 49-72.

Milner, Helen V., and B. Peter Rosendorff. 1997. "Democratic Politics and International Trade Negotiations." Journal of Conflict Resolutions 41, 1: 117-146.

Mizusaki, Tokifumi. 1993. Sosenkyo deta besu: JED-M deta (28-40) [General election database: JED-M data for 28th through 40th general elections]. Tokyo: LDB.

—. 1996. Dai 41 kai (1996 nen) JED-M deta [Japan election data by Mizusaki for the 41st general election in 1996]. Tokyo: LDB.

- 2000. Dai 42 kai (2000 nen) JED-M deta [Japan election data by Mizusaki for the 42nd general election in 2000]. Tokyo: LDB.

Nielson, Daniel L. 2003. "Supplying Trade Reform: Political Institutions and Liberalization in Middle-Income Presidential Democracies." American Journal of Political Science 47, 3: 470-491.

Norin Suisansho [Ministry of Agriculture, Forestry, and Fisheries]. 2004. Nogyo soseisan-gaku (gaisan) [Synopsis of agricultural production]. Tokyo: Norin Suisansho.

—. Various years. Sakumotsu tokei [Crop statistics]. Tokyo: Norin Tokei Kyokai.

Park, Jong Hee, and Nathan M. Jensen. 2007. "Domestic Political Institutions and Agricultural Policy." American Journal of Political Science 51, 2: 314-329.

Reed, Steven R., and Kay Shimizu. 2007. "Measuring Competitiveness in Multi-Member Districts." Paper presented at the conference "Electoral and Legislative Politics in Japan," Stanford University, June 11-12.

Rodosho [Ministry of Labor]. 1975. Rodo kumiai kiso chosa [Basic survey on labor unions]. Tokyo: Rodosho.

Rogowski, Ronald. 1987. "Trade and the Variety of Democratic Institutions." International Organization 41, 2: 203-223.

Rosenstone, Steven J., and John Mark Hansen. 1993. Mobilization, Participation, and Democracy in America. New York: Macmillan.

Saeki, Naomi. 1997. Jusen to nokyo [Housing loan companies and the agricultural cooperatives]. Tokyo: Norin Tokei Kyokai.

Sasaki, Takeshi., Masaki Taniguchi, Shinichi Yoshida, and Syuji Yamamoto. 1999. Daigishi to kane: Seijishikin zenkoku chosahokoku [Representatives and money: Report on the national survey of campaign finance]. Tokyo: Asahi Sensho. 
Shogenji, Shinichi. 2006. Gendai nihon no nosei kaikaku [Policy reform in Japanese agrofood sectors]. Tokyo: University of Tokyo Press.

Somusho Tokeikyoku [Ministry of Internal Affairs and Communications, Statistics Bureau]. Various years. Kokusei chosa [National census]. Tokyo: Nihon Tokei Kyokai.

Stokes, Susan C. 2005. "Perverse Accountability: A Formal Model of Machine Politics with Evidence from Argentina." American Political Science Review 99, 3: 315-325.

Tatebayashi, Masahiko. 2004. Giin kodo no seiji keizaigaku [Political economy of legislative behavior]. Tokyo: Yuhikaku.

Uchida, Takio. 2002. "Noka kozo no henka to nokyo no soshiki kiban eno eikyo" [Change in the structural features of farm households, and its impact on the organizational foundations of the agricultural cooperatives]. Norin kinyu [Agricultural finance] 55, 7: 24-37.

Watanabe, Osamu. 1998. "Sengo-gata seiji no keisei to noson" [Formation of postwar politics and rural communities]. In Demokurashi no hokai to saisei: Gakusaiteki sekkin [Collapse and renewal of democracy: An interdisciplinary approach], ed. Minami Ryoshin, Masanori Nakamura, and Tamotsu Nishizawa. Tokyo: Nihon Keizai Hyoronsha.

Yamada, Saburo. 1991. "Quantitative Aspects of Agricultural Development." In The Agricultural Development of Japan: A Century's Perspective, ed. Yujiro Hayami and Saburo Yamada. Tokyo: University of Tokyo Press. 